\title{
Owners \& Builders, Their Umpires \& Agents
}

\author{
GEORGE BARNETT JOHNSTON \\ Georgia Institute of Technology
}

\begin{abstract}
The logic of design and building practice in this country can be best understood in terms of gradual shifts in the political economy of construction which issued from colonial times and outward into an advancing frontier. Over three centuries of settlement, pioneers and ostensibly self-sufficient settlers became a symbiotic society, both widely dispersed across the landscape and tightly concentrated in cities. They were comprised of property owners unable to simply build for themselves; and of crafts people building for others, whether for trade or through involuntary servitude, plying their skill in wood, brick, iron, and stone. The notion of an architect could issue from either side of that equation, but each formulation carried embedded relations of class and power, ones we still grapple with today. This paper examines the historical emergence of the idea of the American architect at the contractual intersection of builders' means and owners' ends.
\end{abstract}

\section{INTRODUCTION}

Before we can even begin to imagine an architect on-thescene as owner's agent or master builder, we must first envision a relationship far more fundamental, the one that obtains between Owners and Builders themselves. According to a late-19th century treatise on construction law, "The relation between the builder and the owner is formed exclusively by the contract.." ${ }^{11}$ From this we might wonder, which came first, the architect or the contract? While Vitruvius posited the existence of the architect as an historical fait accompli already deeply embedded in Greco-Roman culture from ancient times, the raison d'être of the architect in America cannot be so quickly assumed. The necessity for and presence of the architect in the settlement of North America was neither functionally nor historically preordained; rather, the role of architect on this continent had to be reestablished in its own right, within an endemic logic of practice.

On the one hand, we might imagine royally entitled owners of landed estates possessing - along with scores of enslaved individuals whose skilled labor they could direct toward an ambitious building goal - some knowledge in science and mathematics, a set of fine drawing instruments, and a personal library with European architectural folios, perhaps of Palladian plates. ${ }^{2}$ In this instance, the royal grantee would serve in effect both as developer and their own architect following a model of English aristocracy. The gentlemanly architect supplied a vision and the necessary resources, guiding craft laborers either directly or organizing them through skilled intermediaries, in the day-to-day execution of their tasks. The second and third sons of those estates, foreclosed as legatees by the customs of primogeniture, might find for themselves a calling as building designer and adviser, an "architect" to others of their same social class.

On the other hand, and in contrast to agrarian narratives, we might imagine a burgeoning city, still fresh within recent memory as a mere settlement, expanding and being subdivided into land lots assigned for private, commercial, or public uses now awaiting their requisite structures. By commission on contract, or increasingly on speculation for profit, loose companies of masons and carpenters, journeymen and apprentices guided by the experience and sometime sketches of their contracting masters, could infill with ample facility the surveyor's grid with a serviceable building fabric. With increasing acumen, such builders' draftsmen might provide plans as a service to their commercial or other clientele, or they might separate from their builder colleagues altogether and distinguish themselves independently with a self-anointed title, "architect." They might also strive in their dealings with clients, some with more and some with less success, to attain the social status and position of gentleman.

Construction customs and building design practices were transplanted to America along with architectural styles, but they adapted to local conditions. They were shaped by, and in turn shaped, the diverse interests and expectations of building instigators, all of whom operated within regionally differentiated notions of commerce and trade. In the late-19th and early-20th centuries, even as the field of architecture was being formalized within a still maturing framework of American business and law, journal editorialists and convention speakers strove to chart the degree of change in the social standing of the profession. While such accounts might vary in objectivity by virtue of the vagaries of memory, their degree of historical proximity, or polemics of progress and decline, they nonetheless present a composite narrative of an emergent idea, the American architect.

\section{"FIFTY YEARS AGO"}

In his role as editor at the fledgling Boston-based journal American Architect and Building News, William Rotch Ware reminisced from his perspective of 1876 upon the state of the profession as compared to the 1820 's: “Fifty years ago, ... [t] men who designed buildings were, ordinarily, the men who built them; and it was only in rare cases, and for structures of 
unusual importance, that the two or three men in the country who made a profession of designing were called upon." ${ }^{3}$ Ware was sanguine about the progress achieved in the public standing of the architecture profession in the intervening decades since the founding of the American Institute of Architects in 1857. He wrote, "The body of architects have gained greatly in influence and respect during the last score of years or so. And the first reason why they have gained is that they have become a body; that is to say, they are now a class of men, fulfilling a special function in a somewhat uniform way, and with more or less of common understanding among them." Ware cautioned, nonetheless, that "even now those relations and usages are far from being universally determined and recognized." Future progress in establishing architects' professional authority as "arbiters in all matters of design" still depended, he insisted, upon professional unity in the establishment of consistent standards of practice, style, and taste in order to gain broad public approbation and support. ${ }^{4}$

The architect of "fifty years ago" was a recurrent theme for succeeding generations striving to stake their progress against fading memories of a receding past. In a speech a decade later at the 1887 AIA convention, architect William $W$. Boyington noted the virtual absence of the profession of architecture from Chicago at the beginning of his career in the 1850's. Addressing methods of practice that prevailed "fifty years ago," Boyington described the direct relationship that then obtained between owners and builders and the gradual emergence and recognition of the profession as he had observed over the course of his career: ${ }^{5}$

When I came to Chicago, thirty-four yeas ago, I found the architects then in practice were recent master builders or contractors. Chicago and the West at that time could hardly be said to require the services of architects separately as such. At that time the structures were just simple buildings. But the builders soon found it would be better for them to have plans made for them, than to spend their time in making plans, so they clubbed together, and induced one of the most apt in drawing plans, to give up contracting and devote his whole time to Architecture, and guaranteed him a compensation of two dollars per day, which should be paid to him, if he did not get business enough to aggregate that amount. ... It was not uncommon to be asked in what the business of an architect consisted. This simply shows that as a profession it was not understood. ${ }^{6}$

Echoing each other from Boston and Chicago, these reminiscences suggest that the architect arose only slowly out of the ranks of master craftsmen, a situation matched in Philadelphia which, Boyington claimed, "in proportion to the number of its inhabitants, put up, in the last fifty years, more buildings without employment of architects on them, than any city in the country." ${ }^{17}$ The changing scope and variety of building within these urbanizing milieus, the changing materials and building systems, called forth a new class of construction intermediary to satisfy dual and sometimes competing demands-accommodating and representing the interests owners; coordinating and supervising the work of builders.

According to New York City architect William P. Bannister, the profession-in-formation was riven in roughly equal numbers between categories of the "real architect" who was a "real gentleman" and the "underworld of architecture" which "sold itself as a miserably paid servant to the builder" of the deplorably overcrowded urban tenements that constituted the "slums of architecture." Indeed, a whole spectrum of practitioners from those times could be grouped under the rubric of architect, all in competition with each other and generally reflecting traits of character drawn more from the clientele of owners or builders they served than from some intrinsic ethical core. According to Bannister, "If they do not give up, they face the competition of "small house" bureaus, "mail order" housing and the "development" corporations to which many of their peers have fled." "' Because so many competing manifestations of the field could be conflated in the public imagination, distinguishing one from the other became a primary concern among the ostensibly more respectable group in the interest of enhancing collective professional esteem.

At the middle of the 19th century, the American concept of "architect" was still fungible. Any number of permutations, called by whatever names, remained present in memory and still available as possible realities. Owners could act as their own architects or their own principle contractors assembling and paying the necessary labor; alternately, builders could provide designs to owners, or even build speculatively for themselves. The role of architect was thus a hybrid and variable arrangement, comprised by parts of project originator and project executor to which was added a third part, mediator between the other two. The architect might be a superintendent on behalf of the owner; might engage directly with the various contractors of the trades almost like a general contractor, hiring them, directing their work, and disbursing their pay. No single practice model prevailed; rather, in broad application, necessary capabilities could be variably joined and then deployed to meet the contingent needs of a situation, responsive to local customs and to whatever client motives and builder skills might pertain.

Fifty years later, however, the ambiguities of architects' social and vocational origins had been largely forgotten or elided. Instead of arising out of the building crafts to achieve mastery of artful execution, "real architects" of recent memory were assumed to have all been artists, dilettantes, and gentlemen steeped in their discipline but aloof from both the messy practicality of building and the ethical morass of business. 
Where these competing and complementary roles had coexisted historically under the slippery signifier of "architect," over time that name was rationalized and formalized in ever more exclusive terms. It was circumscribed within the strictures of civil society and an ever increasing division of labor to promote a singular professional ideal. ${ }^{10}$

The process of professionalization - through institutional organization, education, and licensure - tended to favor the dominance of patrician interests over democratic values even as self-serving motives were promoted in the name of the public good. ${ }^{11}$ Social closure of the ranks of a profession could serve as a means of market control as well as a marker of competence to bolster public trust. In essence and effect, the ethical imperatives of professionalization imposed a necessary boundary between the same and the other - between a uniform class of authoritative practitioners and all those others, pretenders and imposters; between architects and so many amateurs, owners, builders, or engineers. An unintended consequence of asserting such a broad and exclusive claim to the title of architect, however, was to entitle other groups' overlapping and competing territorial claims.

\section{THE UNIFORM CONTRACT OF 1888}

In 1887, a special committee of the American Institute of Architects was appointed "to confer with like committees from the Western Association of Architects, and the National Association of Builders, on the subject of Uniform Contracts, and to prepare and adapt, in such Committee of Conference, a form of contract properly protecting the interests of owner and contractor."12 The impetus for this effort had been longcoming, but the matter became more urgent when the call came from a newly organized group of master builders to join efforts in common cause, to bring uniformity and fairness to the transactions between owners and builders. ${ }^{13}$ By this juncture, contractors considered architects - such as those represented by their respective professional organizations - to be more "the legal representatives and agents of the owners" than they were adepts from among the builders' fold. ${ }^{14}$ Builders therefore sought a conversation with architects, in their role as surrogate s for owners, in the interest of shaping a "unity of practice," by developing uniform contractual standards that could be applied nationwide.

In a speech at the first convention of the National Association of Builders, Peter B. Wight described the pervasive chaos of the contracting system then in effect, in which "each [architect] is a law unto himself. He lays down the law as to the practice in his own office and expects everyone doing business there to comply with it. He does not think of the position in which the builder is placed, often a very embarrassing one." 15 With each architect as agent promulgating their own proprietary contractual forms on behalf of their respective clients, contractors found themselves at a disadvantage and in a constant state of uncertainty with regard to the obligations they were expected to fulfill. Wight emphasized the fundamental conflict that resides at the intersection of the architect's dual roles - as agent for the owner and as impartial referee between that same owner and the builder in cases of conflict. According to Wight: "There is an old theory that the architect is a sort of middle man or umpire to stand between the owner and contractor and see that both get their rights. This is only a theory. It is not the fact. It is not the law.... The architect is the agent of the owner. The courts have so decided. He is paid by him, and only by him if he is an honest man. ... He is, therefore, doing his duty when he is looking after the owner's interests. The contractor is doing his duty to himself by looking after his own interests. If he expects the architect to do this he is very much mistaken"16

A half-century distant from the days of the American architect being identified primarily as a master builder, builders now considered architects to be agents of the owner instead. Once architects were cast into that representative role, builders challenged their credibility to serve in the mediating role of impartial judge. Wight seemed to accept the inevitability of this structural conflict in observing, "The main defect ... in contracts in which the architect is referee, has arisen from the difficulty of defining his duties as superintendent..."; therefore, he proposed as a measure of remedy, "it is of the utmost necessity that the contracting parties agree as to the nature and extent of the referee's duties and authority." The builders' association was pressing, albeit still in congenial terms - "I have no desire to be harsh with our brethren of the architectural profession" - to circumscribe the authority of the architect within the bounds of a legal compact. ${ }^{17}$ Builders' parallel purpose was to assert their own agency and position, one "which entitled them to be ranked as members of a profession and not merely as tradesmen and mechanics."18

Correspondence commenced between the architects' and builders' organizations early in 1888 focused on the task of coming to terms on the substance of a uniform contract. According to the annual report of the AIA's Committee on Uniform Contracts, much of the back and forth of negotiation was handled by that committee's chair, Oliver P. Hatfield, and the secretary of the National Association of Builders, William H. Sayward. Working primarily from a draft previously prepared by the American Institute of Architects, the joint committees "continued their sessions through two days and one evening, until they had brought the form of contract sought for into a satisfactory shape, and then referred it to the Chairman and Secretary, as a sub-committee, to have it printed and again submitted to the members of the Committee for their further consideration." The final version of the contract was printed after a few more minor changes and amendments. ${ }^{19}$

What seems on the surface to have been a straightforward and congenial meeting of minds nonetheless belies continuing 
apprehensions on both sides. The terms codified in the contract cast contractors in a decidedly subordinate position in relation to the architect's assumed authority as the owner's delegatee. The first three clauses of the contract established in quick succession the architect's role as owner's agent, ${ }^{20}$ as author of the drawings and specifications as well as their ultimate interpreter, ${ }^{21}$ and as adjudicator between owner and contractor of adjustments in contract cost due to changes in project scope. ${ }^{22}$ An additional provision allowed contractors' appeals to a board of arbitration in cases where the architect's judgment was challenged. In contrast to embedded contractual characterizations of the architect as impartial, fair, and reasonable, the contractor's modus operandi was assumed to be that of refusal, neglect, or failure. ${ }^{23}$

To explain why builders might have agreed to such asymmetrical terms, it must be recognized that at that time regularization of mutual contractual obligations in any form was superior to the caprices contractors then confronted. "One contract may have three pages of fine print, which he can hardly read without glasses, and another may have one page of coarse print; and so they may vary through all the possible changes from one to ten. In each case, it is not expected that he will demur to anything; but he is expected to sit down and affix his name." ${ }^{24}$ At their convention the following year, the president of the National Association of Builders admitted certain caveats about their contract negotiating accomplishments: "I may be pardoned here for saying that while we do not claim to have made a 'perfect contract,' yet this one is far in advance of any that has been used heretofore in establishing equitably the duties and responsibilities of owners, architects, and contractors." 25

The report of the builders' Committee on Uniform Contracts sought to reassure the organization's membership that the new contract could be modified in the future to meet new challenges, that "the machinery for perfecting the [contract] form is at hand" through reconvening the joint committees. Voices arose nonetheless from the Cincinnati and Buffalo delegations with recommendations for further modifications of the contractual form. While these objections were set aside for the moment - architects' agency for owners, the assumed fairness of their judgments, the insufficiencies of the arbitration clauses - the reverberations of these conflicts would still linger. ${ }^{26}$ As the builders became more familiar with the Uniform Contract in practice and in use, the previously acknowledged flaws become less and less palatable to them. Almost a decade later, however, the concerns still festered even as the builders abstained from direct confrontation for change.

For their part, neither did architects universally approve of all the provisions of the Uniform Contract. The Boston Society of Architects, for example, continued to promote their own "suggestive form of contract" and even engaged a young attorney and future Supreme Court Justice Louis D. Brandeis to compare its merits to those of the Uniform Contract promoted by the AIA. Brandeis found the stipulation in the Institute's form that made the architect the agent of the owner to be "objectionable" in that it "increases unreasonably the architect's responsibilities." ${ }^{27} \mathrm{He}$ also found fault with the Uniform Contract's arbitration provisions and the manner by which the cost of changes was decided, echoing in substance the builders' concerns. At the AIA's own convention in 1901, the committee assigned to stewardship of the contract admitted: "It is urged by some that it is too long; that there are provisions contained in it which should be more properly put into the preliminary clauses of a specification, and by others, that although it is too long, it still omits clauses which should be found therein. ... Some object to the arbitration clauses, others highly commend them. Some object to recognizing the architect as agent of the owner. Some object to the insurance clause, and others think both clauses should remain." 28

A year later, the committee reported back the AIA convention on several revisions to the Uniform Contract, the results of a joint meeting with cohorts from the National Association of Builders. "The most notable omission," they observed, "is the clause which designates the architect as agent of the owner." While seemingly final, the implications of this relation would remain an ongoing legal and professional concern. Also clarified were the architect's ownership of the drawings and specifications as instruments of service, "and that the charges for their use and for he services of the architect are to be paid by the owner, thus condemning the unprofessional practice which has obtained in some quarters of making contractors pay for detail drawings." Finally, the arbitration clauses were clarified "to make it more effective, hoping thereby to facilitate settlements out of court should disputes arise that from any cause could not be adjusted by the architect." ${ }^{29}$ By these measures, the project hegemony that architects imagined for themselves began yielding to contractors' concerns.

Despite both builders' and architects' ongoing dissatisfactions with the uniform contract, its broad adoption by owners, builders, and architects effected changes in the status quo of design and building practice nationwide. As architects recognized, "One great advantage of a uniform contract is that its long continued use establishes by that fact its reasonableness, and creates a series of requirements which are universally recognized as fair and equitable. It also creates confidence on the part of the owner that he is properly and amply protected, and on the part of the contractor that there are no hidden traps requiring a lawyer to search out and detect lest he unwittingly sign away his rights." ${ }^{\prime 30}$ The Uniform Contract was new tool of practice contributing to architects' own emergent professional uniformity, and it was cast from a die mostly of their own design. In helping draft a standardized form of agreement, architects asserted 
a uniquely representative role for themselves in between Owners and Builders. They were no longer master builders and not quite full agents on Owners' behalf, but they were originators and proprietors of their own instruments of service, the drawings and specifications where their authority did reside.

\section{CODA}

By the end of the 19th century, architects of various stripes had emerged out of the circumstantial gaps in a myriad of improvised contracts in order to fill the necessary roles - as advisor, agent, organizer, designer, drafter, contractor, superintendent, administrator, or arbitrator of disputes. Counter to American constitutional logic, they seemingly combined executive, legislative, and judicial roles into one. Architects might embody in variable combinations the refined sensibilities of a well-informed clientele, practical wisdom distilled from the acumen of a master builder, or the insight into human nature requisite of an able leader and impartial judge. They might also reflect the more exploitative traits to which each of those cohorts was prone under the sway of increasingly predatory business concerns. At the beginning of the 20th century, in order both to counter those commercial tendencies and to comport with their inexorable logic, architectural practice was being formalized as a profession based upon standards of a well-meaning but paternalistic code.

Even prior to the sedimentation of roles from the once fluid universe of building practice, what had mediated the relationship between an owner and a builder was some ad hoc form of agreement - whether written, oral, or implied. That gentlemanly covenant was addressed to immediate conditions that locally prevailed. ${ }^{31}$ At the turn of the century, the division of labor in society depended upon increasingly specific contracts as part of the dual process of integration and regulation promoting social cohesion. ${ }^{32}$ Once the conditions of the contract were standardized and concretized, they redounded back to the modus operandi of practice. Whether the builders realized it at the time or not, when they invited the architects to confer with them on the terms of a uniform contract, they were not merely initiating an incremental challenge to the status quo; rather, they were shaping new precedents that could be tested in court. They were codifying a mechanism for change. In a manner analogous to that played by a contract mediating between opposing parties, the architect emerged as a crucial social mechanism facilitating a process of exchange between owners and builders. ${ }^{33}$ At the turn of the 20th century, the architect instantiated this paradox of reciprocity, one that still functions and bedevils today, as both agent and arbitrator of exchange.

\section{ENDNOTES}

1 T. M. Clark, Architect, Owner and Builder before the Law : A Summary of American and English Decisions on the Principal Questions Relating to Building, and the Employment of Architects, with About Eight Hundred References, Including Also Practical Suggestions in Regard to the Drawing of Building
Contracts, and Forms of Contract Suited to Various Circumstances (New York: London, 1894), 180.

2 Such might be the case of Drayton Hall along the Ashley River near Charleston, SC. See Arnold Berke, "Searching for Palladio: How Did One Italian Architect Shape Some of America's Greatest Houses?," Preservation 61, no. 4 (2009): 40-; George W. McDaniel and Carter C. Hudgins, "Mystery at Drayton Hall: The Surprise Apperance of a 1765 Watercolor Sheds New Light on a Palladian Past," Magazine Antiques 177, no. 4 (2010): 148-51. Nearby, archaeologists and historians at Middleton Place are working to better understand the role of enslaved peoples in the shaping of the land and the architecture. Barbara Sullivan Mary Edna Todd Tracey Duell Charles Doyle, Beyond the Fields : Slavery at Middleton Place (Charleston, S.C.: Middleton Place Foundation, 2008). On a more urban and infrastructural scale, architect Carl Anthony has excavated both personal memory and history to reveal the intertwined relationship among race, place, and environmental justice in the U.S. Carl Anthony, The Earth, the City, and the Hidden Narrative of Race, First edition. ed. (New York City: New Village Press, 2017), Biography (bio).

3 "The Need of Unity," American Architect and Building News 1 (1876): 2-3 William Rotch Ware (1848-1917) was the nephew of noted architectural educator William Robert Ware (1832-1915). Henry F. Withey and Elsie Rathburn Withey, Biographical Dictionary of Armerican Architects (Deceased) (Los Angeles: New Age Publishing Co., 1956), 632-33. First published in 1876 the American Architect and Building News was, according to historian Mary Woods, "the first American periodical with a future," having a sustained run until 1938 when it was absorbed by Architectural Record. Mary Woods, "The First American Architectural Journals: The Profession's Voice," Society of Architectural Historians. Journal 48, no. 2 (1989): 118.

4 "The Need of Unity," 2-3.

5 Boyington (1839-1898) was born in Springfield, MA and received some training in architecture in New York under a Professor Stone. He arrived in the Chicago, according to his own account, at about the age of 14. Withey and Withey, 71.

6 W.W. Boyington, "Differences between the Methods of Architectural Practice Prevalent Now and Those of Fifty Years Ago," Proceedings of the 21st Annual Convention of the American Institute of Architects (1887): 102-06.

7 Ibid., 104. Boyington fails to account for the esteemed tradition of very highly skilled master builders that had been long-established in Philadelphia and that exercised a notable influence through its guild organization, the Carpenters' Company of the City and County of Philadelphia.

8 William P. Bannister, "The Practice of Architecture," American Architect 129, no. 5 (1926): 41-42.

9 Ibid., 42.

10 Frank Eugene Kidder, "The Architect as a Builder and as an Engineer," Inland Architect \& News Record 29 (1897): 22. Kidder cites English discourse on the characteristics of the ideal architect.

11 Magali Sarfatti Larson, "Emblem and Exception: The Historical Definition of the Architect's Professional Role," in Professionals and Urban Form, ed. Judith R. Blau, Mark La Gory, and John Pipkin (Albany: State University of New York Press, 1983), 70-76.

12 E.H. Kendall, "Report of Special Committee on Uniform Building Contract," Proceedings of the 21st annual convention of the American Institute of Architects (1887): 69. The short-lived Western Association of Architects was founded in 1884 and merged with the AIA in 1889 . Comprised primarily of mid-western practitioners with a majority of its membership from Chicago, the WAA's more inclusive membership requirements were a significant contrast with the more elitist orientation of the AIA. See Cecil D. Elliott, The American Architect from the Colonial Era to the Present (Jefferson, North Carolina: McFarland \& Co., 2003), 78-81; Mary N. Woods, From Craft to Profession: The Practice of Architecture in Nineteenth Century America (Berkeley: University of California Press, 1999), 38-42

13 A cogent and informative account of the history of the development of the AIA's standard contracts can be found in American Institute of Architects, The American Institute of Architects Official Guide to the 2007 AIA Contract Documents (Hoboken, N.J.: John Wiley \& Sons, 2009), 12-37. Besides the establishment of a standard schedule of charges for architectural services in the years following the Civil War, calls had been issued as early as the 1870's from leaders of the profession such as Richard Morris Hunt and Thomas U. Walter for the establishment of some standard form of construction contract, though none of these efforts was brought to fruition until the late $1880 \mathrm{~s}$.

14 P.B. Wight, "Building Contracts," Inland Architect and News Record 9, no. 4 (1887): 33.

15 Ibid., 33-34. Wight (1838-1925), it is noted in the speech transcript, was at that time the General Manager of the Wight Fireproofing Company of Chicago, an innovator in fireproof doors, and in that capacity apparently ranked himself among the mechanics, master builders, and contractors in attendance at the convention. He was, however, also an architect and had been active within the American Institute of Architects since 1866 while still in practice in New York and served as that organization's national secretary 1869-1871. Withey and Withey, 657; American Institute of Architects, 13, 20-21.

16 Wight, 33. 
17 Ibid.

18 "Talking to the Builders," New York Times, 27 November 1889, 4. The words and sentiment are those of William $\mathrm{H}$. Sayward speaking two years later to the Building Trades Club of New York City about the purpose of organizing builders.

19 See "Report of Special Committee on Uniform Building Contract," Proceedings of the 22nd annual convention of the American Institute of Architects (1888): 62-63. Oliver Perry Hatfield (1819-1891) practiced architecture in New York, was an early member of the American Institute of Architects, serving for a time as the Treasurer of that organization. Withey and Withey, 271. William Sayward (1845-19XX) served as Secretary of the National Association of Builders for over fifty years. He was instrumental in negotiating the terms of the 1888 Uniform Contract and remained a force for recognition of builders, and an irritant to architects, throughout his career. Sayward was a contractor in Boston and had represented the Suffolk District in the Massachusetts House of Representatives. According to his family genealogy, He took an active part in the debates on Woman's Suffrage, strongly opposing the measure." In addition it was noted, "Mr. Sayward has been a very popular public reader, possessing rare powers of imitation, combined with a good physique, strong facial expression and great dramatic force." Charles A. Sayward, The Sayward Family: Being the History and Genealogy of Henry Sayward of York, Maine and His Descendants: With a Brief Account of Other Saywards Who Settled in America, Variation: Genealogy \& Local History (Ipswich, Mass.: Independent Press, 1890), Microfiche (mfc); Master microform (mmc), 154-55.

20 "The Contractor shall and will well and sufficiently perform and finish, under the direction, and to the satisfaction of [insert name] Architect (acting as Agent of said Owner), all the work included in the [insert project description] agreeably to the drawings and specifications made by the said Architect,..."

21 "Should it appear that the work hereby intended to be done, or any of the matters relative thereto, are not sufficiently detailed or explained on the said drawings, or in the said specifications, the Contractor shall apply to the Architect for such further drawings or explanations as may be necessary, ... and in event of any doubt or question arising respecting the true meaning of the drawings or specifications, reference shall be made to the Architect, whose decision thereon, being just and impartial, shall be final and conclusive.

22 "Should any alterations be required in the work shown or described by the drawings or specifications, a fair and reasonable valuation of the work added or omitted, shall be made by the Architect, and the sum herein agreed to be paid for he work according to the original specification, shall be increased or diminished as the case may be."

23 "Should the Contractor at any time refuse or neglect to supply a sufficiency of properly skilled workmen, or of materials of the proper quality, or fail in any respect to prosecute the work with promptness and diligence, or fail in performance of any of the agreements on [ ] part herein contained, such refusal, neglect or failure being certified by the Architect, the Owner shall be at liberty, after three days written notice to the Contractor, ..."

24 Wight, 33.

25 National Association of Builders of the United States of America, "Official Report of the Third Annual Convention " (Boston [etc.]: National Association of Builders of the United States of America., 1889), 6.

26 Ibid., 36-43.

27 Louis D. Brandeis, "Suggestive Form of Contract Printed for the Boston Society of Architects," American Architect \& Building News 37 (1892): 7.

28 American Institute of Architects, Proceedings of the Thrity-Fifth Annual Convention of the American Institute of Architects (Washington, DC, 1901), 42.

29 "Important Revision of the Uniform Contract," Inland Architect \& News Record 40 (1902): 36.

30 American Institute of Architects, Proceedings of the Thrity-Fifth Annual Convention of the American Institute of Architects (Washington, DC, 1901), 42.

31 Clark, 180

32 According to Durkheim, "To be sure, when men unite in a contract, it is because, through the division of labor, either simple or complex, they need each other. But in order for them to co-operate harmoniously, it is not enough that they enter into a relationship, nor even that they feel the state of mutual dependence in which they find themselves. It is still necessary that the conditions of this co-operation be fixed for the duration of their relations. The rights and duties of each must be defined, not only in view of the situation such as it presents itself at the moment when the contract is made, but with foresight for the circumstances which may arise to modify it. Otherwise, at every instant, there would be conflicts and endless difficulties. We must not forget that, if the division of labor makes interests solidary, it does not confound them; it keeps them distinct and opposite. Even as in the internal workings of the individual organism each organ is in conflict with others while co-operating with them, each of the contractants, while needing the other, seeks to obtain what he needs at the least expense; that is to say, to acquire as many rights as possible in exchange for the smallest possible obligations. Émile Durkheim, "Progressive Preponderance of Organic Solidarity," in Émile Durkheim on Morality and Society, Selected Writings, ed. Robert Neelly Bellah (Chicago: University of Chicago Press, 1973), 97-98.

33 As Georg Simmel suggested, "Exchange is not merely the addition of the two processes of giving and receiving. It is, rather, something new. Exchange constitutes a third process, something that emerges when each of those processes is simultaneously the cause and effect of the other. Through this process, the value which the necessity of self-denial for an object imparts to it becomes an economic value." Georg Simmel, "Exchange," in On Individuality and Social Forms; Selected Writings, ed. Donald N. Levine (Chicago: University of Chicago Press, 1971), 57. 